\title{
Powers of the President in the Romanian SEMI-PRESIDENTIAL SYSTEM. CRITICAL FEATURES
}

\author{
Neliana Rodean ${ }^{1}$ \\ Faculty of Law, University of Verona, Italy \\ email: neliana.rodean@univr.it
}

RODEAN, Neliana. Powers of the President in the Romanian semi-presidential system. Critical features. International and Comparative Law Review, 2014, Vol. 14., No. 2, pp. 71-82. DOI: 10.1515/iclr-2016-0052.

\begin{abstract}
In Romania, a semi-presidential system characterized by an exaltation of the powers of the President of the Republic, there would be critical observations to be reported in relation to this institution. More precisely, it refers to the constitutional provisions which weaken the President among the political institutions and could also lead to different interpretations.

First of all, the paper examines the President as popularly elected body but that does not reflect fully the will of the nation. Secondly, its oath violated the freedom of religion and if the wording will not be changed, will continue to constitute a discrimination against other non Orthodox President that could be elected. Moreover, the Romanian legal system is characterized by an independence of the President in its relationship with the Parliament but on the one hand, that does not mean that the President is more powerful in the event of dissolution of the Parliament and the other hand, the Parliament is completely independent in determining its competences in relations with the office of the Presidency.
\end{abstract}

Keywords: Romanian President, constitutional provisions, oath, prorogatio, Parliament's dissolution

\section{Romanian President as entity representing the Romanian nation}

The Constitution of Romania lacks of an express regulation concerning the quality of the Romanian President as entity representing the Romanian citizens.

Title III of the Romanian Constitution, as reviewed in $2003^{2}$, regulates the Public Authorities, and amongst those, Chapter 1 states the norms regulating the Parliament and Chapter 2 provides the norms regulating the President of Romania as an institution.

1 Assistant Professor of Italian and European Constitutional Law, Faculty of Law, University of Verona, Italy.

2 Constitution of Romania, updated and republished in the Official Journal No. 767 of October 31, 2003. Amended by Law No.429/2003 in Official Journal of Romania, Part I, No. 758 of October 29, 2003. 
The Parliament is formed by deputies and senators, whom take office by universal, equal, direct, secret and freely expressed vote. As Romanian legal system is a semi-presidential one, also as for the President of Romania, he/she takes office by universal, equal, direct, secret and freely expressed vote. The election is made by the electorate according to the electoral law.

The Constitution expressly establishes that the Parliament is the supreme representative entity of the Romanian people ${ }^{3}$, being elected by the Romanian people, and that the President of Romania represents the Romanian state ${ }^{4}$.

"The state is considered a legal entity, distinct not only from the nation, but also from its bodies", and "the head of state and the Parliament are merely the organs of a legal entity incorporating it, but not identifying with it"5. Any legal entity has a representative, and in this occurrence the state is represented by its President. Therefore, we cannot say that the head of state is the state, and we cannot say that the Parliament is the only representative body of the state. "The Romanian state represents a form of social organization of the Romanian people, and the President of Romania represents the Romanian state and the Romanian people"'.

Moreover, view the taking office procedure - universal, equal, direct, secret and freely express vote -the representative bodies of the Romanian people are the Parliament and the President of Romania and that the fact that the Constitution does not expressly specify this aspect concerning the President, as it is specified concerning the Parliament, cannot offer an argument in sustaining that the institution of the President is disadvantaged by the constitutional provisions from this point of view, but it can determine us to draw attention on the insertion, in the constitutional text, expressly, of the quality of representative entity of the Romanian people that the President of Romania has.

In relation to the representation by the President of the people whom elected him, a subject of debate is the election method, meaning the voting polls.

The Romanian Constitution provides, as mean to elect the President, the majority of the voting polls ${ }^{7}$.Thus, it is declared elected as President, the candidate whom acquired, during the first voting poll the majority of the votes of the electors registered on the electoral lists. If no candidate has this majority, a second voting poll is organised, between the first two candidates established in the

3 The Constitution of Romania, Article 61 para 1

4 The Constitution of Romania, Article 80 para 1

5 D.C. Dănişor, 'Principiile constituţionale ale suveraniţăţii naţionale' [Constitutional Principles of National Sovereignty], 3 Revista de Drept Public [Review of Public Law] (2008,) p. 15

6 D. Brezoianu and M. Oprican, Administraţia publică în România [Public Administration in Romania] (Bucharest C.H. Beck 2008) p. 172

7 The Constitution of Romania, Article 81 paras 2 and 3 
order of the number of votes obtained in the first poll. The candidate obtaining the greatest number of votes is declared elected.

On the basis of a simple mathematical calculus, it could be verified the President's power of representation, both on the first and on the second voting poll. We consider the $9 \mathrm{mln}$ citizens having the right to vote and 4 candidates at the Presidency of Romania (A, B, C, D). If at the first voting poll participate $80 \%$ of citizens having right to vote means that $7,2 \mathrm{mln}$ citizens expressed their vote. The outcome of the voting procedure will be:

$$
\begin{aligned}
& A=30 \% * 7,200,000=2,160,000 \\
& B=25 \% * 7,200,000=1,800,000 \\
& C=17 \% * 7,200,000=1,224,000 \\
& D=8 \% *^{*} 7,200,000=576,000
\end{aligned}
$$

At the second voting poll, the outcome of the voting procedure will be:

$$
\begin{aligned}
& A=53 \% * 7,200,000=3,816,000 \\
& B=47 \% \star 7,200,000=3,384,000
\end{aligned}
$$

In this example, the President shall be candidate A, whom was elected by a number of $3,816,000$, representing $42,4 \%$ of the voting population. Thus, the elected President shall represent the people in a percentage of little more than $42 \%$ out of the citizens. It may be observed that President's power of representation is mathematically limited, but, still enough from a constitutional perspective.

The mathematical power of representation from the second poll is greater than that of the first poll, which may determine us to support the position that the two voting polls must be kept in the President's election procedure ${ }^{8}$.

Nevertheless, this example is an optimistic one, in the sense that it takes into consideration the same voting presence in both polls (and which is greater than $53 \%$ ). In a contrary situation, when the voting presence in the second poll would be much smaller than in the first poll, the percentage that would determine the winner would be much smaller and automatically the power of representation of the newly elected President would be less significant, too.

In this case, the election of the President out of the first poll (even if not with $53 \%$ of the votes) would be imperative. This is not an argument sustaining the constitutional regulation of a single voting poll for presidential elections, since that a better representation may result out of the second poll, but it may be a starting point for re-implementation of the constitutional provisions of Article 81 paragraphs 2 and 3.

Moreover, we draw attention on the legal aspects related to the organization and deployment of the referendum for the dismissal of the President. By the

8 On single voting poll, see D. Brezoianu and M. Oprican 2008, supra n.5, p. 173 
alteration of Article 10, Law 3/2000 concerning the organization and deployment of the referendum ${ }^{9}$, modification declared constitutional ${ }^{10}$, the possibility was retained of "dismissing the President of Romania by the vote of the majority of the citizens participating in the referendum, regardless of how small this participation may be and regardless of the majority of votes necessary to elect the President in this dignity"11.

Besides the express insertion in the constitutional text of the quality of representation entity of the Romanian people held by the President of Romania, it is absolutely imperative that the legislation body do not neglect to respond via constitutional regulation to the following question: "To what extent people's representation is linked to the exercise of presidential function attributions?"

\section{Religious conditioning of the candidate to the function of President of Romania}

Once elected by the people and the elections validated by the Constitutional Court, the President of Romania shall take an oath ${ }^{12}$.

The legal nature of this oath is identified as a condition to start the President's mandate. As this requirement is expressly provided by Article 82 para 2 of the fundamental text, at its non-fulfilment may determine the invalidation of President's mandate. The same sanction is implied in the case of an elected President whom refuses to take the oath.

The text of the oath is also expressly provided by the Constitution, which implies the exactitude with which it must be spoken and the impossibility to derogate from the text. Thus, "I solemnly swear that I will dedicate all my strength and the best of my ability for the spiritual and material welfare of the Romanian people, to abide by the Constitution and laws of the country, to defend democracy, the fundamental rights and freedoms of my fellow-citizens, Romaniass sovereignty, independence, unity and territorial integrity. So help me God!”.

At a first view, the text is as normal as possible, without exaggerations or limitations. Still, we must notice the religious expression ending the oath "So help me God!".

9 In Official Journal No. 84 of 24 February 2000, updated by Government Order No. 41/2012 - amending and supplementing Law No. 3/2000 on the organization of the referendum Official Journal No. 452/2012 and by the Law No. 76/2012 - for implementation of Law No. $134 / 2010$ on the Code of Civil Procedure in Official Journal No. 365/2012

10 Decision No. 420 of May 3, 2007 in Official Journal No. 295 of May 4, 2007

11 See The Opinion of the President of the Chamber of Deputies regarding the constitutionality of the alteration of Article 10 of the Law No. 3/2000 on the organization and the deployment of the referendum, in G. Gîrleşteanu, 'Procedura referendumului' [The Referendum Procedure], comment of the Decision of the Constitutional Court No. 420/2007, 2 Revista Curierul Judiciar [Review of the Judicial Courier] (2008) p. 1-18.

12 Constitution of Romania, Article 82 para 2. 
This expression opens a new path of analysis, namely: is the person participating in the presidential competition religiously conditioned or not?

The Constitution warrants the right to be elected, via its Article 37: "Candidates must have turned, up to or on the election day, at least twenty-three in order to be elected to the Chamber of Deputies or the bodies of local public administration, at least thirty-three in order to be elected to the Senate, and at least thirty-five in order to be elected to the office of President of Romania." A reference is made in the content of this provision to Article 16 para 3 of the fundamental law: "Access to public, civil, or military positions or dignities may be granted, according to the law, to persons whose citizenship is Romanian and whose domicile is in Romania. The Romanian State shall guarantee equal opportunities for men and women to occupy such positions and dignities". By corroborating the two regulations, we hereby notice that the only fundamental requirements a candidate must fulfil in order to be President of Romania are related to the citizenship, the age and the domicile. It must be added the specifications of Article 10, Law No. 370/2004 on the election of the President of Romania ${ }^{13}$ which clearly specify the fact that a person whom has already held two presidential mandates may no longer candidate for a third mandate, as well as the provisions of the articles in Section 2, Chapter II of the same act, referring to political candidates.

Thus, if we were to try an answer to the previous question, the Constitution and the legal texts in force make no reference to any kind of religious conditioning of a candidate to the office of President of Romania. Moreover, Article 29 para 1 of the Constitution warrants the freedom of conscience, including the religious beliefs: "Freedom of thought, opinion, and religious beliefs shall not be restricted in any form whatsoever. No one shall be compelled to embrace an opinion or religion contrary to his own convictions." Maybe this aspect wouldn't have drawn a particular attention if the Article 70 para 1 of the Constitution wouldn't states that the oath taken by the senators and deputies is established via organic law ${ }^{14}$. Moreover, according to the provisions of the Law No. 8/2002 concerning the oath of faith towards the country and its people of the senators and deputies of the Romanian Parliament, represents only a possibility, and not an obligation, and for this, may be replaced with the expression "I solemnly swear on my honour and conscience".

View the quality of President of the country, of senators and deputies as representatives of the Romanian people, the absence from the legislation in force of a religious condition that would limit a person from being a candidate for the

13 In Official Journal nr. 887 of 29 September 2004, updated by the Law No. 76/2012 in Official Journal No. 365 of 30 May 2012 and Government Order No. 44/2012, in Official Journal No. 606, Part I, of 23 August 2012

14 Constitution of Romania, Article 70 para 1: "Deputies and Senators shall begin the exercise of their office on the day the Chamber whose members they are has lawfully met, on condition the election is validated and the oath is taken. The form of the oath shall be regulated by an organic law." 
office of President of Romania, as well as all the above, we hereby consider that the regulation comprised by the Constitution concerning the oath of the President of Romania should be reviewed in the sense that the religious expression "So help me God" should be optional.

\section{Prorogatio of President's mandate via organic law}

The mandate of the President of Romania is of 5 years, it is exerted since the date of the oath and it may be prolonged, via organic law, in case of catastrophe or war ${ }^{15}$.

As stated by Article 63 of the Constitution the mandate of deputies and senators is for a term of office of 4 years, which may be extended de jure in the event of a mobilization, war, siege, or emergency, until such event has ceased to exist.

The two institutions, fundamentally regulated, are representative organs of the Romanian people, are elected by the citizens via direct and freely expressed vote. Thus, there are scholars who argue that, per interpretatio, the people should decide the prolongation of the mandates, for the people elected them in office.

The fact that the mandate of the President may be prolonged via organic law represents a mean of control exerted by the Parliament over the institution of head of state. Moreover, even if the fundamental law establishes two reasons that might lead to the prolongation of President's mandate, respectively the state of catastrophe and the state of war, it is also the fundamental law that confers deputies and senators the possibility, and not the obligation, to establish the existence of a certain occurrence that might determine the prolongation of President's mandate.

The reasons behind the de jure prolongation of senators and deputies mandate are expressly established by the Constitution and refer to the state of mobilization, war, siege or emergency. The gravity of the situations determining the prolongation of Parliament member's mandate is nothing superior to the gravity of the two reasons that might precede the prolongation of President's mandate, under Parliament's authorisation. The state of war is, in fact, a common cause determining the prolongation of the mandate of the two dignities, with the sole difference that the effects it produces on these prolongations may vary.

As the constitutional text allows the interpretation, on time of war, Parliament's mandate shall be de jure prolonged, but it may not be the case of President's mandate. This depends on how the Parliament chooses to interpret the necessity of President keeping office or, on the contrary, the necessity to organize presidential elections.

15 Constitution of Romania, Article 83 para 3: „The term of office of the President of Romania may be prolonged, by an organic law, in the event of war or catastrophe". 
The state of war is a de facto occurrence, which endangers the safety of the state, and the President of Romania, whom stands as warranty of the national independence, territorial unity and integrity, must remain in office until the de facto situation will allow the organization of presidential elections. In fact, in such a situation, the priority of all public authorities is to get the country out of the war.

At least for the reason of the state of war, the mandate of the President of Romania should be prolonged de jure, and not via organic law.

Whereas the second reason that may lead to the presidential mandate's prolongation is concerned - the state of catastrophe - the scholars highlighted the fact that this notion is not juridical defined, which allows every law researcher to assign "catastrophe" to a multitude of significations ${ }^{16}$. To allow a unitary interpretation of this notion with valences that may determine the prolongation of the mandate of the President of Romania, we believe that we must clarify its meaning in a normative act. This regulation is imperative in order to limit the discretionary power of the Parliament, on the grounds of Article 83 para 3 of the Constitution, and specifically to limit the various possible meanings of the notion of catastrophe.

Thus, it is ensured the respect of the principle ubi lex non distinguit, nec nos distinguere debemus. The application of this legal principle to the analysed occurrence is equivalent to the fact that as long as the Constitution does not specify the meaning of the notion of catastrophe, the legislative force will not be able to assign various meanings depending on the de facto situation ${ }^{17}$.

Moreover, it could be a solution for a better administration of the issues generated by special situation of dignitary mandates prolongation, respectively what the speciality literature proposes ${ }^{18}$ : the situations determining the prolongation of the mandate of the President of Romania to be the same as those established by the Constitution for the prolongation of Parliamentary mandates.

16 The catastrophe represents an armed aggression from the perspective of the author I. Vida, Puterea executivă şi administraţia publică [The executive power and the public administration], (Bucharest R.A. Official Journal 1994) p. 47. A catastrophe may also be an important railway accident, as D. Brezoianu, Drept Administrativ Român [Romanian Administrative Law] (Bucharest All Beck 2004) p. 299

17 Dănişor, D.C. and Gîrleșteanu, G., 'Procedura referendumului' [The Referendum Procedure], the comment to the Decision of the Constitutional Court No. 147/2007, 4 Revista Curierul Judiciar [Review of the Judicial Courier], (2007), p. 14-35

18 Brezoianu, D., Drept Administrativ Roman [Romanian Administrative Law] (Bucharest All Beck 2004) p. 299 


\section{The dissolution of the Parliament does not mean a more powerful Pre- sident}

The Romanian President has a role of arbiter in the political system; however, there are constitutional provisions that lead to interpretations of the powers of the two bodies elected by the people - the President and the Parliament.

As already referred, in the Title III of the Romanian Constitution the mention of Parliament in the first chapter emphasizes the importance of this institution in the Romanian political system, stressing basically its priority compared to other public authorities, including the President of Romania. This interpretation is supported by the doctrine, where that "Romania Constituent Assembly devoted to the Parliament, traditional institution in democratic States, the first place among public authorities. This settlement of legislative power is the natural result both of a rational arrangement of state institutions whose form of government is a Republic, a representativeness of this authority and the ancient roots of the institution into political and state practice." ${ }^{19}$.

One of the most important duties of President of Romania in relation with Parliament, with major implications in the political, economic and social life of the country, is to dissolve it. The Article 89 of the Constitution provides the possibility that the President dissolves the Parliament and the conditions in which this might happen ${ }^{20}$.

In relation to the possibility conferred by the Constitution in favour of the President, the fundamental law let at President's discretion the attribution to intervene in case the Parliament does not award a vote of confidence for the formation of the Government ${ }^{21}$. Thus, the gravity of the non-achievement by the

19 Ionescu C., Constituția României: legea de revizuire comentată si adnotată cu dezbateri parlamentare [Constitution of Romania: law review commented and annotated with the parliamentary debate] (Bucharest All Beck 2003). See also notes of I. Vida in Constantinescu M. et al., Constituţia României - comentată şi adnotată [Constitution of Romania commented and annotated] (Bucharest Regia Autonomă "Monitorul Oficial” 1992) p 133.

20 Constitution of Romania, Article 89: “(1) After consultation with the presidents of both Chambers and the leaders of the parliamentary groups, the President of Romania may dissolve Parliament, if no vote of confidence has been obtained to form a government within 60 days after the first request was made, and only after rejection of at least two requests for investiture. (2) During the same year, Parliament can be dissolved only once. (3) The Parliament cannot be dissolved during the last six months of the term of office of the President of Romania, or during a state of mobilization, war, siege, or emergency".

21 See the situation of 2009 of resigned Boc Government 1 and the new Government of Lucian Croitoru didn't obtain the Parliament's vote of confidence. Thus, the President considered that, to release political crisis, there is the possibility to invest the Government through a new designation of the same candidate (in that case - the resigned Prime Minister). The Constitutional provisions do not require that the President could give up to the previously designated person, which is why we believe that the President can appoint the same person. See also Rusu, I., 'Discuţii în legătură cu normele constituţionale privind desemnarea candidatului pentru funcţia de prim-ministru de către Preşedintele României’ 
Parliament of one of its attributes - to award a vote of confidence for the formation of the Government - as well as the resolution of the effects that this failure could determine - serious governmental crisis - are two appreciations that only the President may make.

The expression "may dissolve the Parliament" leads us to believe in the existence of an alternative. But what could the President do in such a case? What legal and institutional resort might the President have in order to solve the issues arisen between the most representative organs of the two powers, the Parliament as legislative force and the Government as executive one? These questions are, surely, rhetorical, view that no other solution is offered to the President other than, in order to solve the governmental crisis, to interpret the possibility conferred by the fundamental law as an obligation de facto.

If the President decides to intervene, this may only happen in strict compliance with several requirements expressly imposed by the Constitution.

One of this conditions is to consult with the presidents of the two Chambers and with the leaders of the parliamentary groups. The Constitution expressly highlights the compulsory feature of this consult, which may not be an option, but it does not make the distinction if the outcome of the consult of mandatory or optional. Furthermore, the text does not specify the reason of the consult, but we may understand that this would be linked to the negotiations between the members of the Parliament for the purpose of reaching an understanding concerning the vote of confidence - positive or negative - for the formation of the Government. Practically, President's influence on the outcome of the consult is diminished, for the consult takes place effectively between the presidents of the two Chambers and the leaders of the parliamentary groups. If, following this consult, no solution is found in order to give the vote of confidence for the formation of the Government, the Parliament will be subsequently dissolved and parliamentary elections will be organized.

Although the Constitution regulates in the first paragraph of Article 89 this specific requirement, all other conditions, previous to the consult, must also be fulfilled: that there be two rejected requests for a vote of confidence and that 60 days have passed since the first request. These two are preliminary requirements, preceding the dissolution of the Parliament. The effects of accomplishing these conditions are justified, for they lead to the impossibility to govern the country, so to a serious governmental crisis.

The next requirement provided by the Constitution concerns a situation where the Parliament was already dissolved, and, during an entire year, no new dissolution may occur.

[Discussions about constitutional rules on nomination by President of Romania of the candidate for the office of Prime Minister], 12 Dreptul (2008) p. 108-115.

\section{(c) Palacký University Olomouc, Czech Republic, 2014. ISSN 1213-8770 (print), ISSN: 2464-6601 (online).}


Moreover, for situations such as state of mobilization, war, siege or emergency, when Parliament's mandate is de jure prolonged, the dissolution of the Parliament is not possible. If the case were different, the fundamental regulation according to which Parliament's mandate is de jure prolonged shall have no more applicability.

At a first view, the possibility to dissolve the Parliament represent a power of the President versus the other people representation organ. Nevertheless, view that the President assigns a first-minister whom, at his/hers turn, has the attribution to draft the government programme and the list of Government's members, meaning exactly what it needs to do in order to receive Parliament's vote of confidence, practically Parliament's refusal to award the vote of confidence is grounded on an inappropriate choice made by the President. By failure to award the vote of confidence, the quality of the President to assign a competent representative in order to form a Government is questioned.

The dissolution of the Parliament does not mean a powerful President and this it could be another constitutional disadvantages in the context of the Romanian semi-presidential system.

\section{Balancing the power between Parliament and the President}

In the Romanian legal system, the Regulation of the Parliament, and not the Constitution, establishes the competency in its relationship with the President. The Article 63 para 3 of the Constitution provides one of President's attributions in his relations to the Parliament, respectively to convene the Parliament ${ }^{22}$. The provision makes no distinction if it is an ordinary or an extraordinary meeting, but, view that the Parliament must meet in 20 days at the most since the elections, it may only be an extraordinary meeting.

The paragraphs 2 and 3 of Article 66 of the Constitution state the Parliament convening in an extraordinary meeting: "(2) the Chamber of Deputies and the Senate may also meet in extraordinary sessions, at the request of the President of Romania and (3) each Chamber shall be convened by its president." When analysing this provision, one may notice the following attributions assigned to the President and to the Parliament: the President demands the Parliament's Chambers be convened, and the presidents of the two Chambers convene the Parliament for an extraordinary meeting.

This power of the President may be interpreted as an obligation that must be fulfilled by the Chambers. The fundamental text does not leave this convening in an extraordinary meeting at President's choice, but it expressly provides the obligation of the Chambers to meet upon President's request. Practically, once the President exerts his/hers attribution to request the Chambers to meet in an

22 Constitution of Romania, Article 63 para 3: „The newly elected Parliament shall meet upon convening by the President of Romania, within twenty days of the elections". 
extraordinary session, their convening by their presidents appears as a compulsory obligation ${ }^{23}$.

Nevertheless, the Article 84 paragraphs 2 and 3 of the Regulations of the Chamber of Deputies establish the conditions that must be fulfilled for the convening of the Chamber in an extraordinary meeting: the request must be made by the President of Romania, by the Standing Bureau or by at least one third of the number of Deputies; the request to convene an extraordinary session shall be made in writing; the request shall comprise the agenda and the duration of the session; the agenda must be approved by the Chamber.

It could be made a classification of these objective conditions, related to the quality of the person requesting the convening and the form and the content of the request, as well as a subjective condition, meaning the approval of the agenda by the Deputies.

Furthermore, the sanctions are also established, for failure to comply with these conditions, at Article 84 para 4 of the Rules of Procedure of the Chamber of Deputies. These refer to the fact that the President of the Chamber of Deputies shall not take into consideration those requests for the convening of an extraordinary session that do not fulfil the conditions herein above.

It is not sufficient that the President of Romania exert the attribution stated by the Constitution at its Article 66 para 2, but the request filed for the convening of the Chamber of Deputies must fulfil the conditions of the Chamber established via its Rules of Procedure. The objective requirements may be easily met, as we classified them, but the subjective requirement may determine controversies. The President has nothing to do with this subjective condition, for it depends on the majority of the Deputies expressing their opinion concerning the agenda.

If the Deputies do not adopt the agenda, as the President requests, the President of the Chamber is forbidden from convening the extraordinary session. The same situation applies as for the convening of the Senate in extraordinary session, as it results from the content of Article 81 of the Regulation of the Senate.

In these described situations, is this attribution of the President of Romania an obligation for the Parliament? As expressed by some scholars ${ }^{24}$ the two Chambers of the Parliament establish, for themselves, their specific competency in their relationship with the President and exist the possibility conferred by the Regulations of the Chambers to reject the agenda proposed by the President in

23 Coman-Kund, F. and Ciobanu, A.F., Drept administrativ, Partea I, Sinteze teoretice şi exerciţii practice pentru activitatea de seminar [Administrative Law, Part I, Theoretical Syntheses and Practical Exercises for the Seminary Activity], (Bucharest Universul Juridic 2008) p. 129

24 Brezoianu, D. and Oprican, M. 2008, supra n.5, p. 177 
his request which leads to the non-convening of the Chambers in an extraordinary session.

\section{Conclusions}

In Romania, a semi-presidential system characterized by an exaltation of the powers of the President of the Republic, there are constitutional provisions which represent a weakness for the President through the political institutions and could also lead to different interpretations.

First of all, the President as popularly elected body does not reflect fully the will of the nation. Secondly, with its oath is violated the freedom of religion and it is necessary to make changes to the oath because continue to constitute a discrimination against other non-orthodox candidates that could be elected. Moreover, the Romanian legal system is characterized by an independence of the President in its relationship with the Parliament but, on the one hand, it does not mean that the President is more powerful in case of dissolution of the Parliament, and the other, the Parliament it is completely independent in determining its competences in relationship with the office of the Presidency. 